\title{
KEABSAHAN KONTRAK ELEKTRONIK (E-CONTRACT) DALAM PERJANJIAN BISNIS
}

\author{
David Herianto Sinaga, Fakultas Hukum Universitas Udayana, email: \\ vancodavid42@gmail.com \\ I Wayan Wiryawan, Fakultas Hukum Universitas Udayana, email: \\ wayan_wiryawan@unud.ac.id
}

doi: https://doi.org/10.24843/KS.2020.v08.i09.p09

\begin{abstract}
Abstrak
Tujuan penulisan jurnal ini untuk mengkaji pengaturan bentuk kontrak bisnis berdasarkan peraturan perudang-undangan atau peraturan internasional. Kontrak konvensional telah diyakini sah dan mengikat secara hukum karena pengaturannya yang sudah jelas dan lebih sering digunakan dalam perjanjian bisnis di Indonesia. Kontrak elektronik merupakan bentuk kontrak yang baru dan perlu dikaji lebih jauh untuk memberikan adukasi bagi masyrakat luas di Indonesia mengenai keabsahannya. Penggunaan metode dalam penulisan jurnal ini adalah metode penelitian hukum yuridis normatif untuk memecahkan masalah bentuk kontrak elektronik dan keabsahannya dikaji dari Burgerlijk WetBoek, Undang-undang Informasi dan Transaksi Elektonik dan United Nation Commission Internasional Trade Law. Hasil studi menunjukkan kontrak elektronik adalah kontrak atau perjanjian yang dibuat para pihak melalui sistem elektronik. Peraturan perundang-undangan di Indonesia bahkan internasional tidak pernah menentukan bentuk kontrak dan format kontrak secara mutlak. Para pihak bebas menentukan bentuk kontrak yang disepakati namun tetap mengikuti semua syarat kontrak utama dan telah diatur oleh undang-undang yaitu adanya kesepakatan dari para pihak yang berkontrak. Kontrak elektronik berlaku sah dan mengikat sah secara hukum.
\end{abstract}

Kata kunci : Kontrak, Kontrak Elektronik, Kontrak Konvensional, Perjanjian

\begin{abstract}
Conventional contracts are believed to be valid and legally binding due to clear arrangements and are more often used in business agreements in Indonesia. Electronic contracts are a new form of contract and need to be studied further to provide education for the wider community in Indonesia regarding its validity. The method used in writing this journal is a normative juridical legal research method to solve the problem of the form of electronic contracts and its validity is assessed from the Burgerlijk WetBoek, the Information and Electronic Transactions of Law and United Nation Commission Internasional Trade Law. The results of the discussion found that electronic contracts are contracts or agreements made by the parties through the electronic system. Indonesian legislative and even international regulations never determine the form of contract and contract format in absolute terms. The parties are free to determine the type of contract that is agreed upon but still follows the terms of the contract that are primarily and have been regulated by law, namely the agreement of the contracting parties. Electronic contracts are valid and legally binding.
\end{abstract}

Keywords : Contract, Electronik Contract, Convensional Contract, Agreement

\section{Pendahuluan}

\subsection{Latar Belakang}

Keberadaan peradaban dewasa ini dibuat berubah oleh perkembangan teknologi yang begitu pesat dari waktu ke waktu. Kecanggihan teknologi berdampak pada tatanan adat istiadat, bahasa, pendidikan dan aspek lain yang dialami dan dilakukan oleh manusia. Serba mudah adalah dampak yang diberikan oleh kecanggihan teknologi kepada manusia dalam melakukan pekerjaan. Sebagai contoh telepon genggam untuk berkomunikasi dalam jarak yang jauh, robot diciptakan untuk membantu pekerjaan rumah, internet sebagai koneksi ke berbagai penjuru dunia dan sebagainya. Perkembangan ekonomi di Indonesia melaju cepat 
dalam beberapa tahun belakangan ini. Perkembangan ekonomi yang didampingi perkembangan teknologi yang begitu pesat maka banyak kegiatan ekonomi di Indonesia dilakukan berbasis teknologi pula. ${ }^{1}$ Salah satu bidang yang membawa dampak yang sangat besar bagi masyarakat luas adalah perdagangan secara elektronik atau e-commerce. ${ }^{2}$ Misalnya bisnis online yang melakukan jual beli barang melalui sebuah aplikasi online, pengadaan alat-alat canggih tertentu untuk memproduksi barang yang menghasilkan nilai ekonomi. Perjanjian adalah salah satu aspek penting dalam bisnis yang dilakukan oleh individu dengan individu maupun individu dengan kelompok. ${ }^{3}$

Menurut seorang pakar hukum Prof. Subekti "suatu perjanjian adalah suatu peristiwa di mana seorang berjanji kepada orang lain atau di mana dua orang saling berjanji untuk melaksanakan sesuatu hal" ${ }^{4}$. Perjanjian lahir dari kesepakatan yang dilakukan dua atau lebih orang atau kelompok dan melibatkan dirinya pada perjanjian tersebut. Satu asas fundamental dalam pembuatan perjanjian yaitu kebebasan berkontrak. Dengan adanya kebebasan berkontrak artinya setiap orang bebas memberikan pemahaman bahwa setiap orang bebas membuat suatu kontrak atau perjanjian kepada siapapun dan untuk hal apapun. Secara garis besar Ahmadi Miru dalam bukunya Hukum Kontrak dan Perancangan Kontrak menyebutkan bahwa "kebebasan bekontrak memberikan jaminan kepada siapapun: bebas menentukan apakah ia akan melakukan perjanjian atau tidak, bebas menentukan dengan siapa ia akan melakukan perjanjian, bebas menentukan isi atau klausul perjanjian, bebas menentukan bentuk perjanjian, dan kebebasan lainnya yang tidak bertentangan dengan peraturan perundang-undangan ${ }^{5} . "$

Peradaban teknologi yang canggih menciptakan variasi jasa telekomunikasi berekonomi yang baru di Indonesia. Keberadaan variasi telekomunikasi yang baru tentu harus diikuti oleh keberadaan hukum di Indonesia supaya segala sesuatunya diatur oleh hukum dan kewajiban hukum itu sendiri atas eksistensinya. Masyarakat indonesia juga tentu harus menyadari setiap tindakan yang dilakukan melalui elektronik seperti misalnya jual beli online.

Sistem hukum kontrak di Indonesia diatur dalam pasal 1320 dan 1338 BW (burgerlijk wetboek) terdiri dari kontrak tertulis dan kontrak lisan. Secara klasik penyusunan kontrak perjanjian bisnis di Indonesia adalah kontrak konvensional(penyusunan dilakukan dengan tanda tangan dan pertemuan tatap muka) dengan segala kelebihan dan kekurangannya sendiri dalam penyusunan. ${ }^{6}$ Namun perkembangan hukum yang telah disesuaikan dengan perkembangan peradaban teknologi tidak begitu disadari oleh masyarakat hukum khususnya di Indonesia.

Kontrak elektronik merupakan salah satu variasi baru dalam perjanjian bisnis baik jual beli maupun hal yang berkaitan dengan bisnis. Secara umum banyak orang di Indonesia sebagai pelaku ekonomi baik konsumen, produsen dan distributor tidak sadar bahwa jual beli yang dilakukan melalui sistem elektronik adalah sebuah perjanjian bisnis. Padahal

\footnotetext{
${ }^{1}$ Manap, Marina Abdul. "Kontrak Elektronik: Isu dan Penyelesaian Undang-Undang." Journal of Law and Governance 1.1 (2018), 64

2 Latumahina, Rosalinda Elsina. "Aspek-aspek Hukum Dalam Transaksi Perdagangan Secara Elektronik." Jurnal GEMA AKTUALITA 4, no. 1 (2015): 43

3 Sekarini, Marsha Angela Putri, and I. Nyoman Darmadha. "Eksistensi Asas Kebebasan Berkontrak Berkaitan Dengan Klausula Eksonerasi Dalam Perjanjian Baku." Kertha Semaya: Journal Ilmu Hukum (2014), 3

4 Simanjuntak Ricardo. Teknik Perancangan Kontrak Bisnis, (jakarta, PT. Gramedia, 2018), 14

5 Ahmadi Miru. Hukum Kontrak Dan Perancangan Kontrak (jakarta, Raja Grafindo Persada, 2007), 4 .

${ }^{6}$ Latianingsih, Nining. "Prinsip Tanggung Jawab Pelaku Usaha Dalam Transaksi Elektronik Menurut Undang-Undang Informasi Dan Transaksi Elektronik." Jurnal Ekonomi E Bisnis PNJ 11.2 (2012), 73
} 
transaksi komersial elektronik (e-commerce) merupakan bentuk bisnis non-face dan non-sign (tanpa tatap muka tanpa tanda tangan). ${ }^{7}$ Terkait dengan permasalahan yang terdapat dalam latar belakang di atas, maka penulis membuat e-jurnal ; "Keabsahan Kontrak Elektronik (econtract) dalam Perjanjian Bisnis"

\subsection{Rumusan Masalah}

Berdasarkan permasalahan yang terdapat dalam latar belakang di atas maka untuk memperoleh dan menjamin kepastian hukum tentang kontrak elektronik, jurnal ini ditulis untuk memecahkan dua permasalahan yaitu:

1. Apakah itu kontrak elektronik atau e-contract?

2. Bagaimanakah keabsahan kontrak elektronik dalam perjanjian bisnis? (berdasarkan Kitab undang-undang hukum perdata, Undang-undang Informasi dan Transaksi Elektronik dan United Nation Commission Internasional Trade Law)

\subsection{Tujuan}

Jurnal ini ditulis dengan tujuan memberikan edukasi kepada semua masyarakat sebagai pelaku ekonomi yang menggunakan media elektronik dalam jaringan internet tentang kontrak elektronik berkaitan dengan kekuatan hukumnya sebagai kontrak perjanjian bisnis.

\section{Metode Penelitian}

Penelitian merupakan suatu kegiatan ilmiah yang berkaitan dengan analisa dan kontruksi yang dilakukan secara metodologi, sistematis dan konsisten ${ }^{8}$. Jenis metode yang digunakan dalam jurnal ini adalah metode penelitian hukum yuridis normatif, karena dalam membahas masalah nantinya dipergunakan aturan-aturan hukum yang masih berlaku serta bahan-bahan kepustakaan sebagai sumber utama dalam penelitian ${ }^{9}$. Kontrak elektronik jika dikaji menurut BW (burgerlijk WetBoek) maka kontrak elektronik tidak bisa dibahas karena kebiasaan yang terjadi adalah kontrak berupa kontrak konvensional. Sedangkan dalam undang-undang no.19 tahun 2016 tentang undang-undang Informasi dan Transaksi Elektonik, kontrak elektronik tidak dibahas secara detail. Pendekatan penelitian dilakukan dengan pendekatan kasus dan pendekatan perundang-undangan. Pendekatan kasus dilakukan dengan menelaah kejadian-kejadian beberapa masyarakat yang menggunakan teknologi untuk keperluan bisnis. Pendekatan perundang-undangan dilakukan dengan mengkaji peraturan tentang kontrak yang sah menurut hukum positif Indonesia maupun internasional. Jenis penelitian yang digunakan dalam jurnal ini yaitu dengan penelitian deskripstif. Jenis penelitian ini bertujuan untuk menjelaskan bagaimana pengguna media elektronik menggunakan kontrak elektronik dan mengikat secara hukum.

\section{Hasil dan Pembahasan}

\subsection{Pengertian Kontrak Elektronik}

Perkembangan hukum perjanjian adalah munculnya kontrak elektronik (e-contract) sejak diperkenalkan dalam UNCITRAL (united nations comission on internatioanl trade law) pada tahun 1996 dan terbitnya UU nomor 11 tahun 2008 yang selanjutnya diperbaharui menjadi UU nomor 19 tahun 2016 tentang Informasi dan Transaksi Elektronik. Jika dicermati pembahasan kontrak elektronik dalam UNCITRAL (United Nation Commission Internasional

7 Tumangkar, Totok. "Kabsahan Kontrak dalam Transaksi Komersial Elektronik." Hukum Dan Dinamika Masyarakat 10, no. 1 (2016): 34

8 Soerjono soekanto. Pengantar Penelitian Hukum (Jakarta, Cet.III, UI Press, 1984), 8

${ }_{9}$ Amiruddin dan Zainal Asikin. Pengantar Metode Penelitian Hukum (Jakarta, PT. Raja Grafindo Persada, 2004), 166 
Trade Law) dan undang-undang informasi dan transaksi elektronik tidak satu pun menjelaskan secara detail apa itu kontrak elektronik dan bagaimana bentuknya. Alhasil kontrak elektronik diartikan berbeda-beda dan bahkan ada yang keliru.

Secara umum kontrak elektronik diartikan sebagai kontrak dalam yang dibuat dalam bentuk elektronik. Kegiatan transaksi elektronik mengakibatkan adanya perikatan atau hubungan hukum secara elektronik dengan memadukan jaringan berbasis komputer dengan sistem komunikasi yang selanjutnya difasilitasi dengan jaringan internet atau jaringan global. ${ }^{10}$ Berdasarkan pengetahuan tersebut maka perjanjian yang di digitalisasi seperti misalnya surat-surat perjanjian di-scan atau diketik untuk dijadikan soft copy dianggap sebagai bentuk dari kontrak elektronik atau e-contract. Pemahaman yang keliru tentang kontrak elektronik banyak terjadi di zaman digital pada saat ini. Berangkat dari pasal 4 UNCITRAL (United Nation Commission Internasional Trade Law) :

"as between parties involved in generating, sending, receiving, storing or otherwise processing data messages, and except as otherwise provided, the provisions of chapter III may be varied by agreement"

(seperti antara pihak-pihak yang terlibat dalam menghasilkan, mengirim, menerima, menyimpan atau memproses pesan data, dan kecuali sebagaimana ditentukan lain, ketentuan bab III dapat bervariasi berdasarkan perjanjian)

UNCITRAL tidak menyebut bentuk kontrak secara langsung namun memberi petunjuk tentang bagaimana sahnya suatu kontrak perjanjian. Meski prinsip semua perjanjian adalah sama yaitu kesepakatan, bentuk kontrak elektronik bisa bervariasi sesuai dengan media yang berkembang istilah ini disebut "variation by agreement." Dalam e-contract, jaringan elektronik digunakan untuk melakukan offer and acceptance, atau dikenal dengan sebutan EDI (electronic data interchange). Dengan suatu bentuk yang berbeda atau lebih tepatnya baru dari offer and acceptance maka sangat beralasan jika UNCITRAL (United Nation Commission Internasional Trade Law) menyebutnya dengan variasi.

Beberapa kontrak elektronik yang umu digunakan dalam perjanjian bisnis adalah sebagai berikut : 11

a) Kontrak elektronik mail adalah suatu kontrak yang dibentuk secara sah melalui komunikasi email. Penawaran dan penerimaan dapat dipertukarkan melalui email atau kombinasi dengan komunikasi elektronika lainnya, dokumen tertulis atau faks

b) Suatu kontrak dapat juga dibentuk melalui website dan jasa online lainnya, yaitu suatu website menawarkan penjualan barang dan jasa, kemudian konsumen dapat menerima penawaran dengan mengisi suatu formulir yang terpajang pada layar monitor dan mentrnsmisikannya

c) Kontrak yang mencakup direct online transfer dari informasi dan jasa. Website digunakan sebagai medium of communication dan sekaligus sebagai medium of exchange

d) Kontrak yang berisi Electronik Data Interchange (EDI), suatu pertukaran bisnis melalui secara elektronik melalui komputer milik para mitra dagang (trading Partners)

e) Kontrak "melalui internet yang disertai dengan lisensi click wrap dan shrink wrap software yang di download melalui internet lazimnya dijual dengan suatu lisensi click wrap. Lisensi tersebut muncul pada monitor pembeli pada saat pertama kali software akan dipasang dan calon pembeli ditanya tentang kesediaannya menerima persyaratan lisensi tersebut. Pengguna diberikan alternatif “ $i$ accept" atau " $i$ don't accept". Sedangkan

10 Santoso, Agus, and Dyah Pratiwi. "Tanggung Jawab Penyelenggara Sistem Elektronik Perbankan Dalam Kegiatan Transaksi Elektronik Pasca Undang-Undang Nomor 11 Tahun 2008 tentang Informasi dan Transaksi Elektronik." Jurnal Legislasi Indonesia 5.4 (2018), 75

11 Biondi, Glenn. "Analisis Yuridis Keabsahan Kesepakatan Melalui Surat Elektronik (E-mail) Berdasarkan Hukum Indonesia." Premise Law Journal 19 (2016), 3 
shrink wrap lazimnya merupakan lisensi yang dikirim dalam suatu bungkusan misalnya disket atau compact disc.

Penjelasan di atas memberi isyarat bahwa kontrak elektronik (e-contract) dapat diartikan sebagai perikatan atau hubungan hukum yang dilakukan secara elektronik dengan memadukan jaringan dari sistem informasi berbasiskan komputer dengan sistem elektronik yang dilakukan dua orang atau lebih dengan menggunakan komputer atau jaringan berbasis internet. Jurnal yang ditulis oleh Mieke Komar kantaatmaja memberi masukan bahwa kontrak elektronik bisa berbentuk apa saja. Aktivitas yang dilakukan antara penjual dan pembeli berbasis elektronik dan dengan jaringan elektronik bisa dianggap telah membuat suatu kontrak elektronik. Chat online melalui aplikasi tertentu antara dua orang atau lebih untuk menyepakati sesuatu dianggap telah membuat suatu perjanjian elektronik dan secara hukum telah dianggap sah dan memiliki kekuatan hukum. Hal ini yang perlu diketahui oleh masyarakat modern tentang perkembangan teknologi termasuk tentang perkembangan hukum untuk perjanjian bisnis.

\subsection{Keabsahan Kontrak Elektronik dalam Perjanjian Bisnis}

\subsubsection{Syarat-syarat Sahnya Suatu Kontrak}

Bentuk perjanjian atau kontrak akan menjadi hukum dan mengikat para pihak yang menyepakatinya, hanya mungkin terjadi apabila perjanjian atau kontrak tersebut telah memenuhi syarat-syarat sahnya suatu kontrak. Berdasarkan pasal 1320 BW (Burgerlijk Betboek) ada empat syarat sahnya suatu kontrak:

a. Adanya kesepakatan pihak-pihak yang berkontrak

Kesepakatan (agreement) di antara para pihak yang berkontrak bukan hanya menjadi syarat berlakunya kontrak di Indonesia tapi juga berlakunya kontrak secara universal dalam ketentuan kontrak di negar-negara lain. Kesepakatan adalah persesuaian pernyataan kehendak antara satu orang atau lebih dengan pihak lainnya. ${ }^{12}$ Kesepakatan yang merupakan pertemuan antara penawar (offer) dari suatu pihak yang mengajukan penawaran (offeror) dan juga penerimaan oleh pihak lain yang menjadi tujuan dari diajukannya penawaran (offere) tersebut merupakan dasar dari timbulnya kewajiban dari satu sisi dan sisi lain yang harus dipenuhi oleh para pihak yang berkontrak ${ }^{13}$.

Pasal 1320 BW menjadikan kesepakatan (agreement) sebagai salah satu dari 4 syarat fundamental sahnya suatu perjanjian atau kontrak dan hal ini berbeda dengan UNCITRAL (common law) yang tidak langsung menjadikan kesepakatan sebagai dasar sahnya suatu perjanjian tetapi lebih kepada unsur-unsur terjadinya kesepekatan tersebut seperti misalnya penawaran dan penerimaan. Namun bila ditelaah lebih dalam makna keduanya adalah sama karena penawaran dan penerimaan akan menghasilkan kesepakatan.

b. Pihak-pihal berkontrak memiliki kapasitas atau kewenangan hukum

Kecakapan untuk melakukan tindakan hukum merupakan kewenangan yang diberikan dan dijamin oleh hukum baik terhadap orang pribadi dan juga orang korporasi (legal entity) sebagai subjek pendukung hak dan pelaksana kewajiban. Kecakapan untuk melakukan tindakan ataupun hubungan hukum untuk dan atas kepentingan pribadi adalah berbeda dengan kewenangan melakukan tindakan hukum untuk dan atas

12 Dewantara, Gede Eka Prasetya, and I. Wayan Novy Purwanto. "Keabsahan Kontrak Perdagangan Secara Elektronik (E-CONTACT) Ditinjau dari Pasal 1320 Burgerlijk WetBoek." Kertha Semaya: Journal Ilmu Hukum 8, no. 1 (2019): 8.

13Simanjuntak Ricardo. Teknik Perancangan Kontrak Bisnis (Jakarta, PT. Gramedia, 2018), 212-213 
kepentingan suatu badan hukum (legal entity) ${ }^{14}$. Seseorang diperbolehkan membuat perjanjian apabila ia memenuhi persyaratan dalam undang-undang. ${ }^{15}$

Jika subjek hukum adalah seorang pribadi maka haknya untuk melakukan perbuatan hukum dapat dimulai setelah orang tersebut berumur 21 tahun atau telah dewasa dan seorang yang bertindak sebagai subjek hukum dari dan untuk sebuah badan hukum maka seorang tersebut adalah seorang yang memiliki jabatan penting dalam badan hukum tersebut. Misalnya perseroan terbatas (PT), maka orang yang berhak menjadi subjek hukum untuk melakukan suatu tindakan hukum yaitu direksi atau seorang yang ditunjuk oleh direksi untuk melakukannya.

Namun dalam pasal 1329 BW (burgerlijk wetboek) menegaskan bahwa setiap orang setiap orang cakap berkontrak, kecuali bila undang-undang menyatakan tidak cakap. Ketidakcapakan seseorang dalam berkontrak diatur pula dalam pasal 1330 BW(Burgerlijk WetBoek):

1) Orang belum dewasa

Orang dewasa berdasarkan pasal 1330 BW adalah seorang yang telah berusia 21 tahun atau di bawah 21 tahun tapi sudah menikah. Namun dalam hal dalam peraturan perundang-undangan di Indonesia masih terjadi perbedaan pengertian tentang dewasa. Hal ini terbukti bahwa dewasa menurut UU perkawinan no.1 tahun 1974 bahwa orang yang telah berusia 18 tahun telah dapat melakukan perbuatan hukum tanpa diwakili orang tua atau wali.

Kedewasaan menjadi catatan penting bagi para pihak untuk membuat kontrak agar suatu kontrak nantinya sah dan mengikat secara hukum. Meski masih ada ketentuan yang tumpang tindih, namun baiknya haruslah mengikuti salah satu peraturan yang berlaku, misalnya mengikuti ketentuan pasal $1330 \mathrm{BW}$.

2) Mereka yang ditaruh di bawah pengampuan

Meskipun seseorang telah berumur 21 tahun namun ada kemungkinan lain seseorang tersebut dianggap tidak cakap melakukan perbuatan hukum atau berkontrak. Misalnya faktor cacat mental, dungu, sakit mata dan orang-orang di bawah pengampuan tidak dapat melakukan tindakan hukum.

3) Orang-orang perempuan, dalam hal yang ditetapkan oleh UU, pada umumnya semua orang kepada siapa UU telah melarang membuat persetujuan tertentu. Pasal 108 dan 110 BW menjadi dasar bahwa perempuan tidak dapat melakukan suatu perbuatan hukum perdata. Namun hal itu telah dihapus sejak terbitnya SEMA no.3 tahun 1961 dan mempertegas tidak ada perbedaan perempuan dan laki-laki dalam melakukan suatu tindakan hukum atau kontrak.

c. Objek kontrak yang disepakati jelas

Dalam membuat kontrak harus memuat suatu hal tertentu. Hal tertentu yang dimaksudkan adalah isi prestasi sebagai objek perjanjian harus jelas dan paling sedikit ditentukan jenisnya. Hal ini sangat penting untuk dapat bagaimana mengukur bagaimana para pihak menjalankan prestasi masing-masing terhadap hal-hal yang telah disepakati.

Bila hal-hal yang disepakati tidak jelas maka akan timbul ketidakjelasan kontrak di mana "para pihak dapat dianggap melakukan suatu transaksi seperti membeli kucing dalam karung, yang dapat mengakibatkan kontrak tersebut batal demi hukum demi keberlakuannya. Menurut Prof. Subekti, S.H, bahwa perjanjian" tanpa objek yang jelas

14 Ibid, hal.265

15 Kharisma, Dona Budi. "Keabsahan dan Landasan Kekuatan Mengikat Kontrak Elektronik melalui Telemarketting Ditinjau dari Hukum Perjanjian di Indonesia." PhD diss., UNS (Sebelas Maret University), (2013): 16 
maka perjanjian tersebut semula tidak pernah dilahirkan perjanjian dan tidak pernah ada suatu perikatan ${ }^{16}$.

Peraturan perundang-undangan terkait tidak akan mempermasalahkan para pihak untuk memperjanjikan barang-barang yang baru ada di kemudian hari sebagai pokok isi dari perjanjian maupun jumlahnya baru ada setelah perjanjian penutup, asalkan tatacara pemenuhan prestasi dari perjanjian ata kontrak tersebut jelas diatur.

d. Kausa kontrak halal

Kausa menurut Prof. Subekti adalah isi ataupun maksud dari suatu perjanjian. Pernyataan yang keliru jika kausa diartikan sebagai alasan seseorang menyepakati suatu perjanjian. Jadi kausa tidak sama dengan motif. Ahli hukum yang lain yakni Prof. Wirjono Prodjodikoro menyatakan :

"dalam pandangan saya, causa dalam hukum perjanjian adalah isi dan tujuan suatu persetujuan, yang menyebabkan adanya persetujuan tersebut"

Maka berdasarkan pendapat kedua ahli hukum di atas dapat diartikan bahwa kausa dapat diartikan sebagai dasar objektif yang menjadi latar belakang terjadinya suatu kontrak.

Kausa tidak halal berdasarkan pasal 1337 BW (Burgerlijk WetBoek)yang menguraikan bahwa suatu kausa dari suatu perjanjian tersebut dinyatakan tidak halal apabila dilarang oleh undang-undang atau apabila berlawanan dengan ketertiban umum atau kesusilaan baik. Contohnya perjanjian untuk mengadakan perjudian ataupun perjanjian untuk menyuplai wanita tuna susila ke tempat-tempat hiburan ataupun perjanjian perbudakan. Sebaliknya kausa halal diartikan sebaliknya.

Kausa halal atau tidak halal tidak akan mencapai sasaran bila dilihat secara subjektif (keinginan para pihak untuk yang berkontrak). Misalnya pembelian pisau akan menjadi kausa tidak halal apabila pisau dipandang sebagai alat untuk membunuh seseorang. Kausa halal dan tidak halal harus dilihat secara objektif pada inti dari lahirnya pointpoint dalam perjanjian tersebut.

Perbedaan syarat kontrak berdasarkan BW (Burgerlijk WetBoek) dan UNCITRAL (United Nation Commission Internasional Trade Law) sebenarnya tidak terlalu jauh berbeda. Berdasarkan UNCITRAL, syarat sahnya suatu Kontrak yaitu :

1) Harus ada offer

2) Offer tersebut harus direspon dengan acceptance

3) Pihak-pihak yang berkontrak harus memiliki legal capacity

4) Harus ada concideration (prestasi timbal balik)

5) Memiliki lawfull causa

6) Adanya intention to legal relation

Syarat-syarat di atas, hampi seluruhnya sama dengan empat syarat yang terdapat dalam pasal 1320 KUHPerdata, kecuali pada persyaratan adanya "consideration" dan juga harus adanya "intention to crate legal relation".

\subsubsection{Hal-hal yang Mempengaruhi Keabsahan Suatu Kontrak}

1. Faktor-faktor yang merusak

a. Kalamana elemen kesepakatan cacat atau rusak karena :

i. Kesalahan, maksudnya kelamaan salah satu pihak, atau kedua belah pihak, mengikat kontrak dengan pemahaman yang salah

ii. Misrepresentasi, maksudnya kala mana salah satu pihak didorong untuk mengadakan kesepakatan sebagian karena representasi (peenggambaran, uraian awal) yang keliru atau salah dari pihak lain, penggambaran yang salah tadi tidak menjadi salah satu butir ketentuan kontrak 
iii. Tekanan atau pengaruh yang tidak diharapkan atau pengaruh yang tidak pantas, maksudnya tekanan langsung atau tekanan halus yang diterima dari oleh pihak yang mengikat kontrak

b. Kalamana satu atau lebih pihak-pihak yang berkontrak tidak memiliki kapasitas penuh untuk mengikat kontrak

c. Kalamana kontrak tersebut ilegal

d. Kalamana kontrak itu sebagian atau seluruhnya tidak ada atau kosong atau batal berdasarkan undang-undang

e. Kalamana sebuah kontrak sebagian atau seluruhnya batal menurut hukum perdata karena bertentangann dengan kebijakan publik

f. Kalamana kontrak itu adalah termasuk dalam kategori yang membutuhkan sejumlah formalitas dan formalitas itu tidak ada

2. Kontrak yang Rusak

Kalamana dalam suatu kontrak terdapat suatu faktor yang merusak, konsikuensi hukumnya akan beragam menurut situasi. Sebuah kontrak boleh jadi :

a. Batal atau tak ada atau kosong, artinya kontrak yang batal mutlak, tidak bermakna sama sekali

b. Dapat dibatalkan, artinya kontrak yang menimbulkan konsikuensi-konsikuensi hukum, tapi mungkin dikesampingkan atau diabaikan

c. Ilegal artinya kontrak yang tidak dapat digugat kecuali dalam situasi-situasi khusus

d. Tidak dapat dilaksanakan, maksudnya kontrak yang baik tapi penggugat tidak dapat dapat mengajukan suatu gugatan ke hadapan hukum karena tidak adanya bukti tertulis ketika dibutuhkan, atau karen adanya cacat atau kekurangan kapasitas tergugat untuk mengadakan kontrak.

\subsubsection{Kontrak yang Batal}

1. Kontrak yang Batal Umumnya

Perbedaan antara kontrak yang batal dengan kontrak yang ilegal, yakni kontrak yang batal (berarti juga kosong dianggap tidak ada) tidak memunculkan hak dan kewajiban, tetapi konsekuensi penuh dari keilegalan itu tidak ada ${ }^{17}$.

2. Kontrak yang Dinyatakan Batal oleh Undang-undang

Contoh dari kontrak dalam kategori ini adalah :

- Kontrak anak-anak yang dinyatakan batal oleh undang-undang perlindungan anak tahun 1874

- Kontrak-kontrak taruhan perjudian. Semua kontrak yang bersifat judi atau perjudian adalah batal

- Kontrak yang dibatalkan undang-undang tentang harga jual kembali

\section{Kontrak Taruhan}

Kontrak taruhan adalah kontrak di mana dua orang, yang mengaku sebagai pihak yang berlawanan dan bertaruh untuk sebuah kejadian di masa mendatang yang belum pasti, sama-sama sepakat bahwa, tergantung pada hasil dari kejadian tersebut, salah satu akan memenangkan (memperoleh) sesuatu dari yang lain, dan bahwa yang lain, dan bahwa yang lain akan membayar atau menyerahkan kepadanya sejumlah uang atau taruhan lain; kedua belah pihak tidak memiliki kepentingan apapun dalam kontrak itu kecuali jumlah uang atau taruhan yang membuatnya menang atau kalah ${ }^{18}$. Definisi kontrak taruhan menurut Hakim Hawkins dalam kasus carlill vs Carbolic Smoke Ball Co.

4. Kontrak yang Batal Menurut Hukum Perdata Karena Bertentangan dengan Kebijakan Publik

17 William T. Major. Hukum Kontrak (Bandung, Nuansa Cendekia, 2018), 184

${ }^{18}$ Ibid, 185-186 
Kontrak yang batal dalam kategori ini adalah :

- Kontrak-kontrak untuk merampas kekuasaan pengadilan dari yurisdiksinya

- Kontrak-kontrak yang menodai kesucian pernikahan

- Kontrak-kontrak yang menghalangi kewajiban orang tua

- Kontrak-kontrak dalam pembatasan perniagaan

Kontrak-kontrak yang menyangkal yurisdiksi (kekuasaan untuk mengadili) atau kontrak yang telah disebut di atas bukan ilegal sepenuhnya. Kontrak ini dapat mengikat kecuali dalam hal klausul-klausul yang tidak sesuai dengan kebijakan publik.

Keabsahan kontrak elektronik jika dinilai atau dikaji melalui regulasi hukum terkhususnya hukum kontrak, kontrak elektronik sama sekali tidak menyalahi ketentuan dalam pembuatan kontrak perjanjian bisnis.

Syarat-syarat kontrak elektronik dikaji berdasarkan KUHPerdata pasal 1320 adanya kesepakatan, kecakapan pihak, adanya suatu hal dan suatu yang halal dan inti dari dari suatu perjanjian yaitu adanya kesepakatan. Kontrak elektronik pun dikaji berdasarkan hal yang mempengaruhi keabsahan suatu kontrak, bahwa semua kontrak perjanjian (e-contract atau kontrak konvensional) yang dilakukan oleh para pihak memiliki ketentuan-ketentuan yang diatur oleh undang-undang dalam pembuatan kontrak. Kontrak elektronik dikaji berdasarkan kontrak yang batal menurut KUHPerdata, kontrak elektronik akan sama ketentuannya dengan kontrak konvensional yaitu kontrak perjanjian apapun dilarang membuat perjanjian yang melawan undang-undang. ${ }^{19}$

\section{Penutup}

\subsection{Kesimpulan}

Kontrak elektronik berdasarkan UU nomor 19 tahun 2016 tentang Informasi dan Transaksi Elektronik adalah perjanjian yang dibuat oleh para pihak melalui sistem elektronik. Syarat sahnya kontrak elektronik secara umum adalah sama menurut Burgerlijk WetBoek dan UNCITRAL (United Nation Commission Internasional Trade Law) yakni adanya kesepakatan dari para pihak, adanya kecakapan para pihak untuk melakukan perbuatan hukum, adanya pokok persoalan tertentu dan suatu sebab yang halal. ${ }^{20}$ Hal ini menjadi dasar sahnya suatu kontrak meski bentuk kontrak berbeda. Hal-hal yang memengaruhi keabsahan suatu kontrak tidak terletak pada bentuk kontrak yang dibuat melainkan dari subyektifitas dan obyektifitas kontrak tersebut. Suatu kontrak dapat dianggap tidak sah atau batal demi hukum biasanya terjadi jika kontrak tersebut melanggar syarat-syarat perjanjian. Suatu kontrak batal demi hukum sama halnya terjadi dengan hal-hal yang memengaruhi keabsahan suatu kontrak. Kontrak yang dibuat dengan melanggar ketentuan-ketentuan yang diatur oleh undang-undang tentu akan batal demi hukum.

\subsection{Saran}

Masyarakat di seluruh dunia terkhusus di Indonesia telah menggunakan media elektronik dalam kehidupan sehari-hari. Penggunaan media elektronik biasanya digunakan untuk media sosial, game bahkan pekerjaan. Hal yang terpenting dalam bermedia elektronik adalah menyadari dan mengetahui segala sesuatu yang dilakukan dalam teknologi itu sendiri. Seperti halnya jika melakukan transaksi jual beli online dan yang paling marak saat ini adalah mengetahui bahwa segala sesuatu yang terjadi dalam proses jual beli mulai dari

${ }^{19}$ Pebriarta, I. Kadek Ari, and AA Ketut Sukranatha. "KEABSAHAN KONTRAK ELEKTRONIK DALAM KAITAN DENGAN KECAKAPAN MELAKUKAN PERBUATAN HUKUM OLEH PARA PIHAK." Kertha Semaya: Journal Ilmu Hukum (2015), 7

${ }^{20}$ Syafriana, Rizka. "Perlindungan konsumen dalam transaksi elektronik." DE LEGA LATA: Jurnal Ilmu Hukum 1.2 (2017), 434 
chat, tawar menawar dan hingga suatu kesepakatan, maka itulah salah satu yang disebut sebagai kontrak elektronik.

\section{Daftar Pustaka}

\section{Buku}

Ahmadi Miru. Hukum Kontrak Dan Perancangan Kontrak (jakarta, Raja Grafindo Persada, 2007)

Amiruddin dan Zainal Asikin. Pengantar Metode Penelitian Hukum (Jakarta, PT. Raja Grafindo Persada, 2004),

Simanjuntak Ricardo. Teknik Perancangan Kontrak Bisnis, (jakarta, PT. Gramedia, 2018)

Soerjono soekanto. Pengantar Penelitian Hukum (Jakarta, Cet.III, UI Press, 1984),

Subekti. Hukum Perjanjian (catakan XII, Jakarta, PT.Intermasa, 1994)

William T. Major. Hukum Kontrak (Bandung, Nuansa Cendekia, 2018)

Jurnal

Sekarini, Marsha Angela Putri, and I. Nyoman Darmadha. "Eksistensi Asas Kebebasan Berkontrak Berkaitan Dengan Klausula Eksonerasi Dalam Perjanjian Baku." Kertha Semaya: Journal Ilmu Hukum (2014).

Pebriarta, I. Kadek Ari, and AA Ketut Sukranatha. "KEABSAHAN KONTRAK ELEKTRONIK DALAM KAITAN DENGAN KECAKAPAN MELAKUKAN PERBUATAN HUKUM OLEH PARA PIHAK." Kertha Semaya: Journal Ilmu Hukum (2015)

Manap, Marina Abdul. "KONTRAK ELEKTRONIK: ISU DAN PENYELESAIAN UNDANGUNDANG." Journal of Law and Governance 1.1 (2018): 62-76.

Dewantara, Gede Eka Prasetya, and I. Wayan Novy Purwanto. "KEABSAHAN KONTRAK PERDAGANGAN SECARA ELEKTRONIK (E-CONTACT) DITINJAU DARI PASAL 1320 BURGERLIJK WETBOEK." Kertha Semaya: Journal Ilmu Hukum 8, no. 1: 1-13.

Syafriana, Rizka. "Perlindungan konsumen dalam transaksi elektronik." DE LEGA LATA: Jurnal Ilmu Hukum 1.2 (2017)

Kurniasari, Nilam Andalia. "Kontrak Elektronik dalam Hukum Kontrak Indonesia" PhD diss., UNIVERSITAS AIRLANGGA, 2005.

Latianingsih, Nining. "Prinsip Tanggung Jawab Pelaku Usaha Dalam Transaksi Elektronik Menurut Undang-Undang Informasi Dan Transaksi Elektronik." Jurnal Ekonomi $\mathcal{E}$ Bisnis PNJ 11.2 (2012)

Santoso, Agus, and Dyah Pratiwi. "Tanggung Jawab Penyelenggara Sistem Elektronik Perbankan Dalam Kegiatan Transaksi Elektronik Pasca Undang-Undang Nomor 11 Tahun 2008 tentang Informasi dan Transaksi Elektronik." Jurnal Legislasi Indonesia 5.4 (2018)

Biondi, Glenn. "Analisis Yuridis Keabsahan Kesepakatan Melalui Surat Elektronik (E-mail) Berdasarkan Hukum Indonesia." Premise Law Journal 19 (2016)

Tumangkar, Totok. "KEABSAHAN KONTRAK DALAM TRANSAKSI KOMERSIAL ELEKTRONIK." Hukum Dan Dinamika Masyarakat 10, no. 1 (2016).

Kharisma, Dona Budi. "Keabsahan dan Landasan Kekuatan Mengikat Kontrak Elektronik melalui Telemarketting Ditinjau dari Hukum Perjanjian di Indonesia." PhD diss., UNS (Sebelas Maret University), 2013.

Latumahina, Rosalinda Elsina. "Aspek-aspek Hukum Dalam Transaksi Perdagangan Secara Elektronik." Jurnal GEMA AKTUALITA 4, no. 1 (2015).

\section{Peraturan Perundang-undangan}

Kitab Undang-Undang Hukum Perdata 
E-ISSN: Nomor 2303-0569

Undang-Undang Nomor 19 Tahun 2016 Tentang Perubahan Atas Undang-Undang Nomor 11 Tahun 2008 Tentang Informasi dan Transaksi Elektronik 